\title{
BIODIESEL AS A BLENDED FUEL IN COMPRESSION IGNITION ENGINES
}

\author{
K A. Sorate \\ Department of Mechanical Engineering, S. V. National Institute of Technology, Surat, Gujarat 395007, INDIA \\ kasorate@gmail.com
}

\begin{abstract}
Fast depletion of fossil fuels, rapid increase in the prices of petroleum products and harmful exhaust emissions from the engine jointly created renewed interest among researchers to find the suitable alternative fuels. The literature survey shows that the yield of Hibiscus Cannabinus seeds per hectare is about $800 \mathrm{~kg}$ and oil yield is about 120 liter (15-18\% yield). Its by products are fiber and cake, find wide spread applications. It is found that physical and chemical properties of Hibiscus Cannabinus oil biodiesel are very close to the diesel. The authors have conducted experimental tests on a single cylinder diesel engine using Hibiscus Cannabinus oil biodiesel and diesel blended fuel. The performance parameters like thermal efficiency, brake specific fuel consumption, fuel - air ratio and smoke tests are determined through experimentation. The authors concluded that the Hibiscus Cannabinus oil biodiesel biodiesel could be used as an alternative fuel in the blending form.
\end{abstract}

Keywords: Blended fuel, Diesel engine, Exhaust emissions, Hibiscus Cannabinus oil biodiesel -***.

\section{INTRODUCTION}

Internal combustion engine plays an important role in the economic growth of a country. It is directly or indirectly related to all the major sectors of the country. Increasing industrialization and the growing energy demand, limited reserves of fossil fuels and increasing environmental pollution have jointly necessitated exploring some alternate of conventional liquid fuels. Realizing the facts, considerable efforts are in progress globally to develop suitable alternative to the conventional liquid fuels. Vegetable oil based substitute fuels, popularly known as biodiesel, are commercially available in the developed world due to their distinct advantages over conventional diesel fuel.

Large numbers of researchers have introduced the various bio - diesel fuels as an alternative fuels. The contribution of various researchers on the topics is briefed as follows.

1. Karanji oil blend with diesel are formed with acceptable thermal efficiencies as fuels for diesel engines

2. The soybean oil methyl ester behaved comparably to diesel fuel in terms of performance and rate of heat release. The methyl ester fuel gave lower hydro-carbon emissions and smoke number than diesel fuel at optimum operating conditions [1].

3. Jathropha oil has been successfully used on a single cylinder diesel engine blended up to 30 percent with diesel. Exhaust emissions are also in prescribed limit [2]. alternative to a diesel. Table I shows comparison of some selected specifications of Hibiscus Cannabinus oil biodiesel (B100) and that of diesel. The thermo physical properties of Table I show that, the Hibiscus Cannabinus biodiesel oil having properties near to the diesel and can be a leading fuel for diesel engine in blending form with that of diesel.

Table1: Comparison of properties of specifications of diesel and $\mathrm{HC}$ B100

\begin{tabular}{|c|c|c|}
\hline $\begin{array}{c}\text { Standard } \\
\text { Specifications }\end{array}$ & $\begin{array}{c}\text { Standard } \\
\text { Specifications } \\
\text { of Diesel }\end{array}$ & $\begin{array}{c}\text { Standard } \\
\text { specifications } \\
\text { of HC B100 }\end{array}$ \\
\hline Specific Gravity & $0.82 / 0.84$ & 0.89 \\
\hline Flash Point & $50{ }^{\circ} \mathrm{C}$ & $130{ }^{\circ} \mathrm{C}$ \\
\hline Carbon Residue & 0.15 or less & 2.01 \\
\hline Cetane Value & 50.0 up & 32 \\
\hline Distillation Point & $350^{\circ} \mathrm{C}$ & $230{ }^{\circ} \mathrm{C}$ \\
\hline Sulphur \% & $\begin{array}{c}1.2 \% \text { or } \\
\text { less }\end{array}$ & 0.12 \\
\hline Calorific Value & $\begin{array}{c}42500 \\
\mathrm{~kJ} / \mathrm{kg} .\end{array}$ & $\begin{array}{c}36500 \\
\mathrm{~kJ} / \mathrm{kg} .\end{array}$ \\
\hline Pour Point & $10^{\circ} \mathrm{C}$ & $8{ }^{\circ} \mathrm{C}$ \\
\hline Viscosity & $2.1 \mathrm{cSt}$ & $4.56 \mathrm{cSt}$ \\
\hline
\end{tabular}

The main purpose of this paper is to investigate for the suitability of Hibiscus Cannabinus (HC) oil biodiesel as an 


\section{AGRICULTURE DATA OF HIBISCUS}

\section{CANNABINUS CROP}

Hibiscus Cannabinus crop is from a family of minor fiber crops. It has two important species namely Hibiscus Cannabinus and Hibiscus Sabdariffa. The production of Hibiscus Cannabinus is done in various state of India namely Andra Pradesh, Tamil Nadu, Bihar, Assam, West Bengal and Maharashtra. A warm and humid climate suits for Hibiscus Cannabinus crop. The new released verities of Hibiscus Cannabinus are: HS 4288, AMV 1, and HC 583. One of the verity HC 583 is described as follows; The new improved HC 583 has, more or less, smooth green stem, with an irregular light flush of red pigment, the pigmentation increasing with maturity. The leaf is entire and flowers are large, the sepals are green, with red spots. The petals are lemon yellow, with deep crimson throat. Seeds are grayish, black, and more angular. A thousand seeds weight $32 \mathrm{gm}$ the variety is quick growing and its attainable height is between 400 and $500 \mathrm{~cm}$ in warm humid regions, and less in drier areas [3]. Table II shows the agricultural production process of Hibiscus Cannabinus Crop. The seeds are processed in simple ghan (one of the oil extraction machine) in village level. After processing oil is filtered to remove small dust particles [4] Biodiesel is produced by transesterification process.

Table 2:- Agricultural production process data of HC Crop

\begin{tabular}{|l|l|l|}
\hline 1 & Selection of seeds & $\begin{array}{l}\text { Use recommended } \\
\text { varieties }\end{array}$ \\
\hline 2 & Season & July to October \\
\hline 3 & Sowing time & June - July. \\
\hline 4 & Seed rate & $\begin{array}{l}15-17 \mathrm{~kg} \text { per ha for } \\
\text { line sowing } \\
6-10 \mathrm{~kg} \text { per ha for } \\
\text { mix crop }\end{array}$ \\
\hline 5 & Sowing & $\begin{array}{l}\text { Drilling } \\
\text { broadcasting }\end{array}$ \\
\hline 6 & Spacing & $\begin{array}{l}22.5 \mathrm{~cm} \text { to } 25 \mathrm{~cm} \text { row } \\
\text { to row }\end{array}$ \\
\hline 7 & Depth of seeding & $\begin{array}{l}3 \text { to } 5 \text { cm in moist } \\
\text { soil }\end{array}$ \\
\hline 8 & Fertilizer & $\begin{array}{l}\text { Application of } 25- \\
35 \mathrm{~kg} \text { nitrogen per } \\
\text { Hector }\end{array}$ \\
\hline 9 & Yield & $\begin{array}{l}\text { Fiber : } 15-18 \mathrm{q} / \text { ha } \\
\text { Seeds: } 10-12 \mathrm{q} / \mathrm{ha}\end{array}$ \\
\hline
\end{tabular}

The seeds are processed in simple ghan (one of the oil extraction machine) in village level. After processing oil is filtered to remove small dust particles The table 3 shows the products of $\mathrm{HC}$ crop and their applications
Table 3: Products of HC crop and their applications

\begin{tabular}{|l|l|}
\hline Products & Applications \\
\hline Seeds & Oil and reproduction \\
\hline Oil & Edible and medicinal \\
\hline Fiber & To make the ropes \\
\hline Cake & $\begin{array}{l}\text { Important foods for } \\
\text { domestic animals }\end{array}$ \\
\hline Leaves & Vegetables \\
\hline
\end{tabular}

\section{EXPERIMENTATION}

The experimental work is carried out on a single cylinder, water cooled diesel engine. Table IV shows the specifications of the diesel engine. The experimental set up is shown in Fig 1. The engine is coupled with a rope brake type dynamometer. The thermocouples are fixed to measure water inlet-outlet temperatures to engine and calorimeter, exhaust gas inletoutlet temperatures to calorimeter and room temperature. These temperatures are shown on digital temperature indicator. Diesel burette is used to measure the specific fuel consumption. Frictional power is measured by Willian's line method. The smoke meter is connected to the exhaust pipe. The smoke meter works on Hartridge principle and the level of smoke was given in Hartridge smoke units [5]-[6].

In the experimental program, first the performance test on 100 percent diesel is carried out and observations are noted down. The various parameters like brake specific fuel consumption, brake power, brake thermal efficiency and mechanical efficiency are calculated. The blends are prepared from volumetric basis. Diesel with Hibiscus Cannabinus oil biodiesel in various percentages are blended and performed. For preparing 10 percent blend, $900 \mathrm{ml}$ diesel is mixed with $100 \mathrm{ml}$ of Hibiscus Cannabinus oil biodiesel. The sample is kept under observation for one week. After one week, authors concluded that the Hibiscus Cannabinus oil biodiesel is completely miscible with diesel. Same procedure is adopted for preparation of blends of 20, 30 and 40 percent blends

Afterwards the performance tests of these blends are carried out in diesel engine by following the same testing procedure as that of diesel and various performance parameters are determined. The performance tests for the various blends are carried out from 10 percent to 40 percent. 


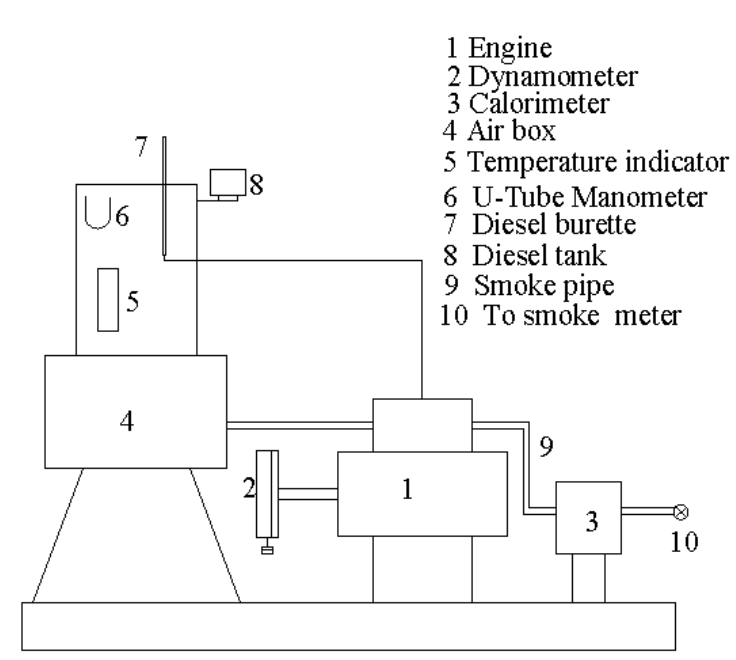

Fig. 1 Experimental setup

When the 45 percent blend is tested on engine, at high loads, the engine was unable to give constant speed. It gets accelerated and decelerated continuously. This is mainly incomplete combustion of the fuel. When 50 percent blend (i.e.500 ml diesel with $500 \mathrm{ml}$ Hibiscus Cannabinus oil biodiesel) was tested, it is observed that the engine was not started at all.

\section{RESULTS AND DISCUSSIONS}

1] It is clear from Fig. 2, smoke emission of diesel is always least than that of blends. From the smoke curve, it is observed that, these curves are nearly parallel to each other. As the blending proportions increases from 10,20, 30 and 40 percent smoke also increases. This increase in smoke is more at high loads as compared to low loads. The blends of 10, 20, 30 and 40 percent shows more smoke level because of the Hibiscus Cannabinus oil biodiesel is slightly heavier than the diesel fuel. The specific gravity of Hibiscus Cannabinus oil biodiesel is 0.89 while diesel having the specific gravity of 0.84 . The literature review shows that heavier fuel with lower Cetane value gives more smoke. The Cetane value of Hibiscus Cannabinus oil biodiesel is 32 while the cetane value of diesel is 50 .

2] Variation in brake specific fuel consumption with varying load and varying blends as shown in Fig.3. From the curve of $10,20,30$ and 40 percent and 100 percent diesel, it is observed that the curves are nearly close to each other

3] Fig. 4 shows the exhaust gas temperatures for 100 percent diesel and 10 percent, 20 percent, 30 percent and 40 percent blends for varying loads. It is observed that, they are slightly parallel to each other. The exhaust gas temperature of all the blends and 100 percent diesel increase as the load increases. It is observed that, at full load the maximum exhaust gas temperature is noted down. This is because; at full load the chemically correct ratio of air and fuel is used. Due to chemically correct ratio of air and fuel, high heat is generated inside the cylinder.

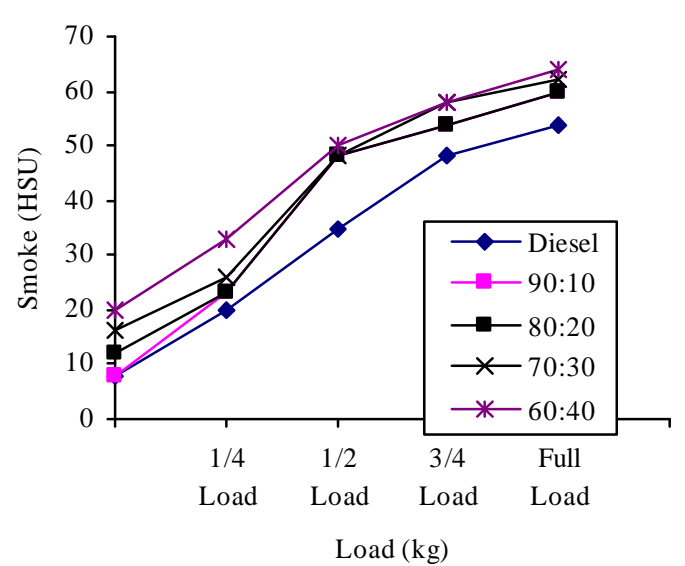

Fig 2 : Smoke Variation of $100 \%$ diesel, $10 \%$, $20 \%, 30 \%$ and $40 \%$ Blend at Different Load Conditions.

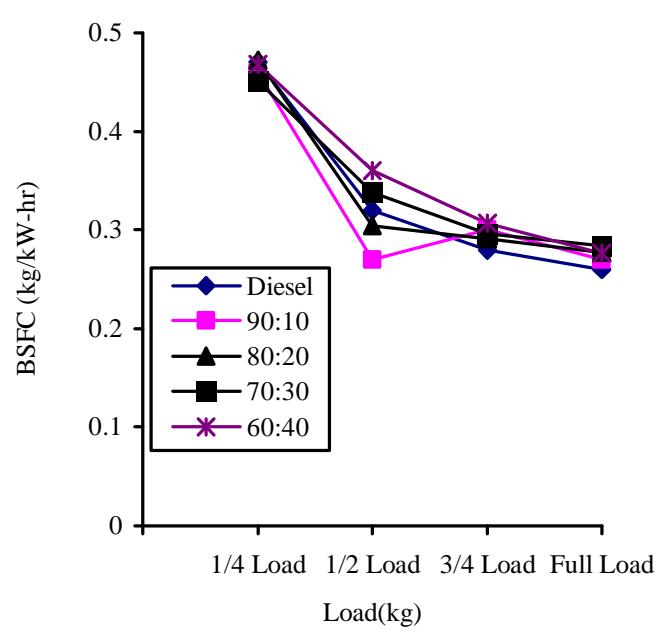

Fig 3 : Variation in BSFC of 100\%, 10\%, 20\%, 30\% and $40 \%$ Blend at

Different Load Conditions.

4] Fig. 5 shows the air fuel ratio of 100 percent diesel and 10 percent, 20 percent, 30 percent and 40 percent blends at different load conditions. From the Fig. 5, it is observed that, the air fuel ratio decreases as the load increases. Air fuel ratio of diesel is less than the various blends of Hibiscus Cannabinus oil biodiesel. At full load, the chemically correct air fuel ratio for 100 percent diesel as well as 10 percent, 20 percent, 30 percent and 40 percent blends is maintained. 


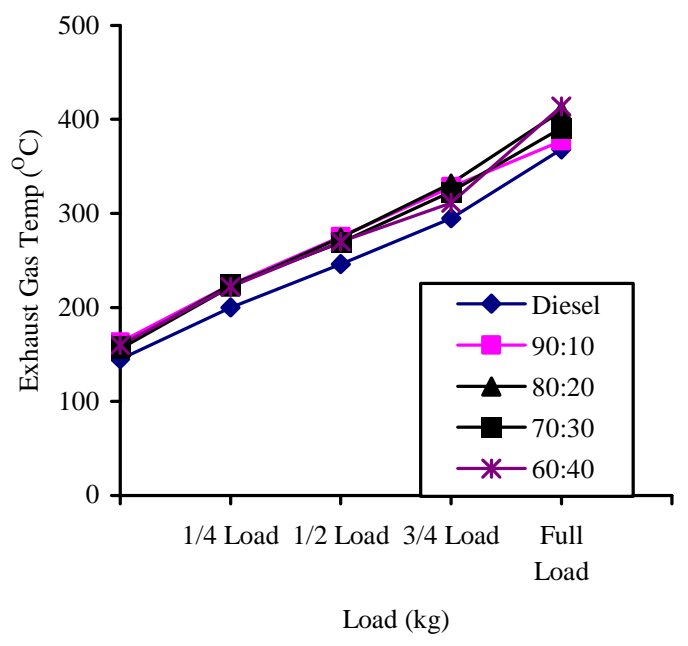

Fig 4 : Exhaust Gas Temperature Variation of $100 \%$ Diesel, $10 \%, 20 \%, 30 \%$ and $40 \%$ Blend at Different Loads.

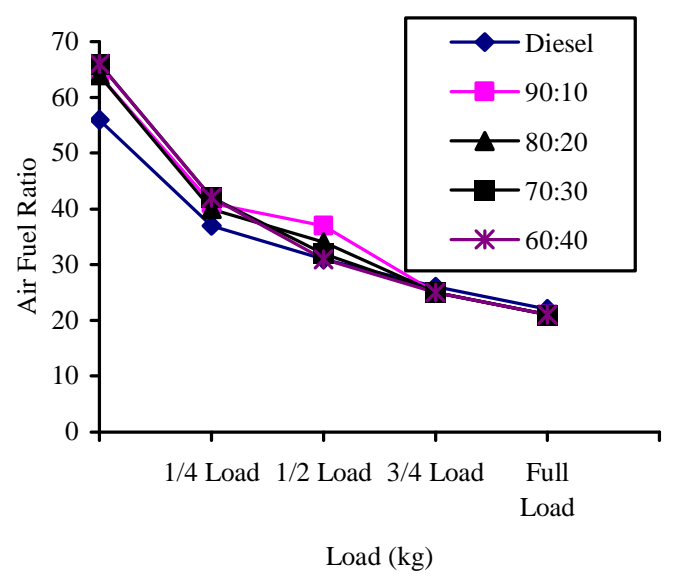

Fig 5 : Variation of Air Fuel Ratio of $100 \%$ Diesel, $10 \%, 20 \%, 30 \%$ and $40 \%$ Blend at Different Load.

\section{CONCLUSIONS}

The following conclusions summarize the experimental results presented in this paper:

1) The Hibiscus Cannabinus oil biodiesel biodiesel properties show that, they are quite comparable with diesel fuel.

2) Viscosity of Hibiscus Cannabinus oil biodiesel biodiesel is s comparable to diesel so that Hibiscus Cannabinus oil biodiesel gets easily mixed with diesel by stirring only. Hence no any chemical method or modification is required for mixing of Hibiscus Cannabinus oil biodiesel biodiesel with diesel.

3) Smoke emission for diesel engine is always less than that of varying blends and at varying loads. Smoke curve tend to be close at initial (zero load) conditions only. For 40 percent blend, there is more smoke at all loads, but it is within the prescribed limit.

4) Brake specific fuel consumption (BSFC) for diesel fuel is more at 10 percent and 20 percent blends. BSFC curves for 30 percent and 40 percent are nearly close to each other.

5) It is observed that, brake thermal efficiency and mechanical efficiency are nearly same for all varying loads and varying blends with pure diesel fuels.

6) Experimental evidence shows that, Hibiscus Cannabinus oil biodiesel biodiesel can be used in blending proportions up to 40 percent with the diesel. Hence it will become an alternative fuel for diesel up to 40 percent blends.

\section{REFERENCES}

[1] School, K.W. and Sorenson, S.C, "Combustion of Soybean Oil Methyl Ester in a Direct Injection Diesel Engine”, SAE Paper No. 930934, pp.1450-1462

[2] Bakshe, P.P., Advani,P.S. and Sapali,S.N., "Esterfied Jathropha Curcas Oil as a Blended Fuel In C.I.Engines", First National Conference on Energy and Fuel Issue of The Future,NCEFIF 2004, Paper No.16, pp. 61-65

[3] Handbook of Agriculture, Indian Council of Agriculture Research (ICAR), New Delhi (India), 1980, pp. 1005-1010

[4] Thamari Selvi J and Rajan Remya, "Bio-fuel Production from Cotton Seed Oil,"2008,Enviromedia,pp. 699-701.

[5] Latey,A.A., Batti,T.S.,Das,L.M. and Gajendrababu, M.K., "Methanol Blended Fuel Investigations on an Injected Single Cylinder Spark Ignition Engine." SAE Paper No.2005-26-031, pp. 475-478.

[6] Malhotra R.K.,Jain Preeti.,Chopra Anju and Maheshawari M.,"Effect of bio - diesel blends on performance and exhaust emissions in passenger car" $S A E$ paper no. 2005-26-032, pp - 479- 482 . 